\title{
Konflik dan Pengaruhnya terhadap Kepuasan Kerja
}

\author{
Novi Desanti, Edy Sutrisno, \& Anggita \\ Jurusan Administrasi Bisnis Politeknik Negeri Pontianak \\ Jalan Ahmad Yani Pontianak 78124 \\ E-mail:desantinovi@gmail.com
}

\begin{abstract}
Abstrak
Konflik di dalam sebuah organisasi dapat terjadi kapan saja dan disebabkan oleh banyak hal juga banyak pihak yang terlibat. Interaksi ini dapat terjadi baik secara vertikal maupun secara horizontal di dalam struktur organisasi. Gesekan-gesekan kepentingan, pemahaman yang berbeda dalam menanggapi suatu hal, aliran komunikasi dan informasi yang kurang lancar, latar belakang budaya dan perbedaan budaya, pendidikan dan tingkat emosi yang berbeda dan lain-lain, merupakan bumerang pagi organisasi itu sendiri. Peneliti ini menggunakan pendekatan penelitian kuantitatif. Sampel sebanyak 26 kuisioner. Teknik analisis data menggunakan analisis regresi sederhana. Dari penelitian ini dapat diketahui jenis konflik, pengaruh parsial penangganan konflik terhadap kepuasa kerja, pengaruh simultan penangganan konflik terhadap kepuasan kerja pada Jurusan Administrasi Bisnis (AB). Pengukuran variabel dilakukan dengan menggunakan skala Likert. Hasil penelitian menunjukkan bahwa: (1) Jenis konflik yang sering timbul di jurusan AB adalah konflik nilai (68\%); (2) Dari hasil uji parsial (uji t) diketahui variabel berintegrasi yang tidak berpengaruh signifikan terhadap kepuasan kerja. Variabel memenuhi memiliki pengaruh yang signifikan terhadap kepuasan kerja. Sedangkan variabel mendominasi, menghindar dan berkompromi berpengaruh signifikan; dan (3) Dari hasil uji simultan diketahui bahwa variabel penanganan konflik berpengaruh secara simultan terhadap kepuasan kerja, sedangkan sisanya dipengaruhi oleh faktor lain yang tidak diteliti dalam penelitian ini.
\end{abstract}

Kata Kunci: Konfik, Penanganan Konflik, Kepuasan Kerja

\section{PENDAHULUAN}

Politeknik Negeri Pontianak (POLNEP) yang merupakan salah satu Lembaga milik pemerintah yang bergerak di bidang pengembangan sumber daya manusia (pendidikan), dimana dalam upaya melakukan fungsinya selalu berinteraksi dengan banyak pihak. Pihak-pihak ini meliput civitas akademika POLNEP sendiri bahkan suatu saat berinteraksi dengan para pemangku kepentingan (stake holder). Interaksi ini dapat terjadi baik secara vertikal maupun secara horizontal di dalam struktur organisasi. Gesekan-gesekan kepentingan, pemahaman yang berbeda dalam menanggapi suatu hal, aliran komunikasi dan informasi yang kurang lancar, latar belakang budaya dan perbedaan budaya, pendidikan dan tingkat emosi yang berbeda dan lain-lain, merupakan bumerang pagi organisasi itu sendiri. Konflik yang berakhir pada pencapaian tujuan dapat diawali disebabkan oleh dampak konflik terhadap kepuasan kerja para anggota organisasi itu sendiri. Seriusnya dari munculnya konflik selayaknya dapat dipahami oleh para pihakpihak yang berkonflik dan pimpinan organisasi dan dapat diselesaikan dengan mengutamakan kepentingan bersama agar 
tidak menimbulkan dampak negatif bagi kepuasan kerja.

Diawali dari pemahaman bahwa konflik jika tidak dapat ditangani dengan baik dapat berdampak pada pencapaian tujuan organisasi sesuai dengan yang telah dijabarkan sebelumnya, maka peneliti merasa tertarik untuk melakukan penelitian dengan judul: "Konflik dan Pengaruhnya Terhadap Kepuasan Kerja (Studi Pada Staf Pengajar Jurusan Administrasi Bisnis Politeknik Negeri Pontianak)."

\begin{tabular}{rrr}
\multicolumn{2}{c}{ Pertimbangan memilih } & lokasi \\
penelitian pada & Politeknik & Negeri
\end{tabular}
Pontianak khususnya staf pengajar Jurusan Administrasi Bisnis dengan mendasarkan pada: Pertama, Jurusan Administasi Bisnis (AB) adalah merupakan salah satu Jurusan yang menghasilkan lulusan Diploma (D3 \& D4) di POLNEP. Jurusan AB memiliki andil yang sangat besar dalam menghasilkan lulusan yang berkualitas. Kedua, Peran serta staff pengajar sangat mempengaruhi terciptanya lulusan yang berkualitas tersebut. Ketiga, peraran staff pengajar di dalam upaya mendukung tujuan itu tidak terlepas dari penanganan dari berbagai konflik yang muncul.

Ada beberapa pertimbangan memilih subjek penelitian tentang Lembaga pendidikan adalah dengan mendasarkan bahwa: Pertama, sumber daya manusia adalah merupakan salah satu faktor produksi yang sangat penting. Kedua, peningkatan kualitas sumber daya manusia yang dihasilkan tidak lepas dari peran serta anggota organisasi yang ada.

\section{TINJAUAN PUSTAKA}

Pencapaian tujuan organisasi baru dapat dilakukan jika terdapat batasanbatasan yang jelas. Pemahamannya adalah bahwa batasan ini menunjukkan mana pihak yang menjadi anggota suatu organisasi dan mana yang bukan. Batasan ini juga memungkinkan adanya pembagian tugas. Menurut Robbins (2006), organisasi adalah kesatuan (entity) sosial yang dikoordinasikan secara sadar, dengan sebuah batasan yang relatif dapat diidentifikasi yang bekerja atas dasar relatif terus menerus untuk mencapai suatu tujuan bersama atau sekelompok tujuan. Sehingga dalam rangka pencaaian tujuan tersebut haruslah memiliki prinsip.

Konflik dipahami oleh banyak pihak adalah sesuatu yang seharusnya dihindari. Pemahaman ini didasarkan bahwa konflik merupakan sesuatu yang berdampak negatif bagi organisasi. Pandangan ini tidak salah, karena dibanyak organisasi kemunculan konflik menimbulkan berbagai hal negatif. Namun dilain pihak memandang konflik sebagai sesuatu yang alamiah dan tidak hanya berdampak negatif namun juga berdampak positif. Robbins (2006) mengemukakan beberapa pandangan mengenai konflik, yaitu:

1. Pandangan Tradisional. Keyakinan bahwa semua konflik membahayakan dan harus dihindari.

2. Pandangan Hubungan Manusia. Keyakinan bahwa konflik meupakan hasil alamiah dan tidak terhindarkan oleh kelompok.

3. Pandangan Interaksionis. Keyakinan bahwa konflik tidak hanya menjadi kekuatan positif dalam kelompok namun konflik juga sangat diperlukan agar kelompok berkinerja efektif. 
Jika dibaca dari berbagai literatur, ada begitu banyak jenis konflik menurut para ahli. Dilihat dari sumber konflik, menurut Kreitner \& Kinicki (2005) ada empat tipe dari konflik, yaitu:

1. Konflik Kepribadian. Pertentangan antarpribadi yang di dorong oleh ketidaksukaan atau ketidaksepakatan yang sifatnya pribadi.

2. Konflik Nilai. Tipe konflik ini sejajar dengan konflik kepribadian. Sama seperti orang-orang yang memiliki gaya yang berbeda-beda yang mungkin saling bertautan.

3. Konflik Antar Kelompok. Konflik diantara kelompok kerja, tim dan departemen adalah ancaman biasa bagi daya saing organisassional.

4. Konflik lintas budaya.

Sedangkan jika dilihat dari pandangan interaksionis, menurut Robbins (2006) ada dua ragam konflik, yaitu:

1. Konflik Fungsional. Konflik yang mendukung sasaran kelompok dan memperbaiki kinerjanya.

2. Konflik Disfungsional. Konflik yang menghambat kinerja kelompok

Untuk dapat membedakan konflik fungsional dan konflik disfungsional, menurut Robbins (2006) juga perlu melihat jenis konflik:

1. Konflik tugas. Konflik atas isi dan sasaran pekerjaan.

2. Konflik hubungan. Konflik berdasarkan hubungan interpersonal.

3. Konflik proses. Konflik atas cara melakukan pekerjaan.

Konflik dapat terjadi baik secara pribadi maupun antar kelompok yang disebabkan oleh pendangan seseorang atau sekelompok orang terhadap nilai-nilai yang ada, konflik dapat berdampak positif maupun negatif bagi organisasi. Dalam upaya penyelesaian konflik yang terjadi, banyak cara atau pendekatan yang dapat diambil, sehingga konflik dapat berdampak positif bagi organisasi. Menurut model Afzalur Rahim (dalam Kreitner \& Kinicki 2005) seorang spesialis konflik lima gaya menangani konflik, yaitu:

1. Berintegrasi (Memecahkan Masalah). Dengan gaya ini pihak-pihak yang tertarik dihadapkan pada masalah dan dengan bekerjasama mengenali masalah, menghasilkan dan memberikan bobot solusi-solusi alternatif, dan memilih solusi.

2. Memenuhi (Memuluskan). Orang yang bersedia memenuhi permintaan mengabaikan kepentingannya sendiri untuk memuaskan kepentingan pihak lain.

3. Mendominasi (Memaksa). Kepedulian pada diri yang tinggi dan rendah untuk orang lain mendorong timbulnya sikap “ Saya Menang, Anda Kalah".

4. Menghindar. Taktik ini dapat melibatkan penarikan diri pasif dari masalah atau menekan masalah secara aktif.

5. Berkompromi. Ini adalah pendekatan memberi dan menerima yang melibatkan perhatian rata-rata baik untuk diri sendiri atau orang lain.

\section{METODE PENELITIAN}

Penelitian ini menggunakan pendekatan penelitian kuantitatif yaitu peneliti mengumpulkan data dengan menetapkan terlebih dahulu konsep, variabel-variabel, indikator-indikator yang berasal dari teori yang sudah ada yang diperoleh oleh peneliti dan kemudian membuat beberapa item pertanyaan dengan menggunakan kuesioner 
untuk pengukuran variabel-variabel tersebut. Metode survey digunakan untuk pengambilan sampel dari populasi dan dengan menggunakan kuesioner sebagai instrumen pengumpulan data yang pokok (Singarimbun dan Effendi, 1995).

Berdasarkan tujuan penelitian yang ditetapkan, maka penelitian ini adalah penelitian eksplanatori (Explanatory Research) yaitu penelitian yang menyoroti hubungan antara variabel-variabel penelitian dan menguji hipotesis yang telah dirumuskan (Singarimbun dan Effendi, 1995). Berdasarkan berbagai penelitian eksplanatori, maka penggunaan jenis penelitian ini adalah tepat untuk mengetahui hubungan dan pengaruh dari variabel independent terhadap sejumlah variabel dependent.

Populasi dalam penelitian ini adalah seluruh staff pengajar Jurusan AB POLNEP yang berjumlah 26 (dua puluh enam) orang. Sedangkan sampel adalah keseluruhan dari populasi. Pengumpulan data dalam penelitian ini dilakukan melalui teknik wawancara, kuesioner, dokumentasi dan observasi.

Skor dari setiap item pertanyaan menggunakan skala Likert. Skala Likert digunakan untuk mengukur sikap dan persepsi seseorang atau kelompok tentang kejadian atau gejala sosial. Alternatif penilaian dalam pengukuran item-item tersebut terdiri dari 5 (lima) alternatif pilihan yang mempunyai tingkatan sangat rendah sampai dengan sangat tinggi (bernilai $1 \mathrm{~s} / \mathrm{d} 5$ ) yang diterapkan secara bervariasi sesuai pertanyaan. Dengan demikian dapat dicapai pengukuran yang tidak hanya menggambarkan kategori atau urutan yang merupakan skala ordinal, tetapi telah dicapai skala interval.
Pengujian validitas dilakukan dengan analisa butir. Sebuah instrumen dikatakan valid, jika koefisien korelasinya $\geq 0,3$ dengan $\alpha=0,05$ (Sugiyono, 2005). Reliabilitas mengarah pada keajegan suatu

alat ukur, dimana tingkat reliabilitas memperhatikan sejauh mana alat ukur dapat diandalkan dan dipercaya (Singarimbun dan Effendi, 1995). Uji realiabilitas instrumen penelitian ini menghasilkan alpha yang telah dibakukan (standarized item alpha) dan nilai alpha ini harus lebih besar dari realiabilitas yang dijinkan dihubungkan dengan jumlah butir pertanyaan yang ada pada kuesioner. Untuk menganalisis data peneliti menggunakan analisis statistik deskriptif, yaitu dengan cara mendeskripsikan data yang telah terkumpul sebagaimana adanya tanpa bermaksud membuat generalisasi hasil penelitian (Abdurrahman dan Sambas Ali Muhidin, 2011). Gujarati (1999) menjelaskan bahwa untuk melakukan pengujian regresi linier berganda terstandarisasi yang memiliki pengaruh langsung, maka digunakan, uji t (individual test). Berdasarkan latar belakang dan tinjauan pustaka yang telah diuraikan sebelumnya, maka konsep penelitian yang diajukan dapat dilihat pada gambar 1 .

\section{HASIL}

Hasil meliputi: (1) hasil uji validitas instrumen penelitian (lihat tabel 1); (2) hasil uji reliabilitas instrumen penelitian (lihat tabel 2); (3) hasil uji partial/uji t (lihat tabel 3); dan (4) hasil uji simultan/Uji F (lihat tabel 4). 
5. PEMBAHASAN

a. Jenis Konflik yang ada Di Jurusan Administrasi Bisnis

Dalam proses interaksi antara suatu subsistem dengan subsistem lainnya tidak ada jaminan akan selalu terjadi kesesuaian atau kecocokan antara individu pelak-sanaannya. Setiap saat ketegangan dapat saja muncul, baik antar individu maupun antar kelompok dalam organisasi. Banyak faktor yang melatar - belakangi munculnya

Tabel 1. Hasil Uji Validitas Instrumen Penelitian

\begin{tabular}{cccc}
\hline Variabel & No Pernyatan & r-hitung & Keterangan \\
\hline Penanganan Konflik & 1 & 0,0141 & Valid \\
& 2 & 0,0290 & Valid \\
& 3 & 0,0034 & Valid \\
& 4 & 0,0111 & Valid \\
& 5 & 0,0223 & Valid \\
Kalid \\
Kepuasan Kerja & 6 & 0,0431 & Valid \\
& 7 & 0,0197 & Valid \\
& 8 & 0,0342 & Valid \\
\hline & 9 & 0,0278 & Valid \\
& 10 & 0,0119 & Valid \\
Valid \\
2 & 0,0322 & Valid \\
& 3 & 0,0134 & Valid \\
& 4 & 0,0309 & Valid \\
& 5 & 0,0176 & Valid \\
\hline
\end{tabular}

Sumber: data olahan 2016

Tabel 2. Hasil Uji Reliabilitas InstrumenPenelitian

\begin{tabular}{ccc}
\hline Variabel & koefisien Alpha Cronbach & Keterangan \\
\hline Penanganan Konflik & 0,832 & Reliabel \\
Kepuasan Kerja & 0,716 & Reliabel \\
\hline
\end{tabular}

Sumber: data olahan 2016

Tabel 3. Hasil Uji Partial (Uji t)

\begin{tabular}{lcc}
\multicolumn{1}{c}{ Variabel } & $\begin{array}{c}\text { Nilai } \\
\text { Signifikansi }\end{array}$ & Keterangan \\
\hline Pengaruh variabel Berintegrasi (X1) terhadap Kepuasan Kerja (Y) & 0,106 & Tidak Signifikan \\
Pengaruh variabel Memenuhi (X2) terhadap Kepuasan Kerja (Y) & 0,007 & Signifikan \\
$\begin{array}{l}\text { Pengaruh variabel Mendominasi (X3) terhadap Kepuasan Kerja } \\
\text { (Y) }\end{array}$ & 0,038 & Signifikan \\
Pengaruh variabel Menghindar (X4) terhadap Kepuasan Kerja (Y) & 0,016 & Signifikan \\
Pengaruh variabel Berkompromi (X5) terhadap Kepuasan Kerja & & \\
$(\mathrm{Y})$ & 0,001 & Signifikan \\
\hline
\end{tabular}

Sumber: data olahan 2016

ketidakcocokan atau ketegangan, antara lain: sifat-sifat pribadi yang berbeda, perbedaan kepentingan, komunikasi yang "buruk", perbedaan nilai, dan sebagainya. 
Perbedaan-perbedaan inilah yang akhirnya membawa organisasi ke dalam suasana konflik. Agar organisasi dapat tampil efektif, maka individu dan kelompok yang saling tergantung itu harus menciptakan hubungan kerja yang saling mendukung satu sama lain, menuju pencapaian tujuan organisasi.

Tabel 4. Hasil Uji Simultan (Uji F)

\begin{tabular}{lcc}
\hline \multicolumn{1}{c}{ Variabel } & Nilai Signifikansi & Keterangan \\
\hline $\begin{array}{l}\text { Pengaruh variabel Penanganan Konflik (X) } \\
\text { terhadap Kepuasan Kerja (Y) }\end{array}$ & 0,018 & Signifikan \\
\hline
\end{tabular}

Sumber: data olahan 2016

Namun, selain dapat menciptakan kerjasama, hubungan saling tergantung dapat pula melahirkan konflik. Hal ini terjadi jika masing-masing komponen organisasi memiliki kepentingan atau tujuan sendiri-sendiri dan tidak saling bekerjasama satu sama lain. Konflik dapat menjadi masalah yang serius dalam setiap organisasi, tanpa peduli apapun bentuk dan tingkat kompleksitas organisasi tersebut. Konflik tersebut mungkin tidak membawa "kematian" bagi organisasi, tetapi pasti dapat menurunkan kinerja organisasi yang bersangkutan, jika konflik tersebut dibiarkan berlarut-larut tanpa penyelesaian. Karena itu keahlian untuk mengelola konflik sangat diperlukan bagi setiap pimpinan atau manajer organisasi.

Dalam penelitian ini digunakan indikator untuk mengukur jenis konflik dilihat dari sumber konflik, menurut Kreitner \& Kinicki (2005) ada empat tipe dari konflik, yaitu:

1. Konflik Kepribadian. Pertentangan antarpribadi yang di dorong oleh ketidaksukaan atau ketidaksepakatan yang sifatnya pribadi.

2. Konflik Nilai. Tipe konflik ini sejajar dengan konflik kepribadian. Sama seperti orang-orang yang memiliki gaya yang berbeda-beda yang mungkin saling bertautan.

3. Konflik AntarKelompok. Konflik diantara kelompok kerja, tim dan departemen adalah ancaman biasa bagi daya saing organisassional.

4. Konflik lintas budaya.

Berdasarkan pengolahan data diketahui bahwa jenis konflik yang sering timbul dijurusan Administrasi Bisnis dengan nilai di atas $60 \%$ adalah konflik nilai (68\%) hal ini dikarenakan setiap orang memiliki gaya yang berbeda-beda. Selain itu juga hal ini disebabkan nilai yang dianut seseorang seringkali tidak sejalan dengan sistem nilai yang dianut organisasi atau kelompok. Dan konflik kepribadian (63\%) hal ini terjadi di dorong oleh ketidaksukaan atau ketidaksepakatan yang sifatnya pribadi. Kedua hal ini dapat terjadi ketika dua orang yang berbeda tidak dapat menerima tindakan yang diambil oleh salah satu dari mereka atau salah satu dari mereka tidak ingin orang lain melakukan suatu tindakan baru. Ciri yang paling jelas dari konflik ini akan tampak ketika seseorang menolak untuk bekerjasama dengan orang lain karena ia tidak percaya kepada orang itu, merasa bahwa orang lain tidak menghargainya atau tidak percaya bahwa orang lain juga memiliki sisi kejujuran sehingga selalu 
muncul kecurigaan terhadap orang itu. Jika seseorang mulai menarik diri atau menghindari orang tertentu, maka hal ini merupakan tanda awal terjadinya konflik. Menurut Kreitner dan Kinicki (1995), manajer atau pimpinan organisasi harus proaktif untuk mengidentifikasikan keberadaan kondisi - kondisi tersebut dalam organisasinya, dan jika salah satu atau lebih dari kondisi itu muncul, maka ia harus segera mengambil tindakan, sebelum kondisi itu menjadi konflik terbuka atau konflik yang nyata (manifest conflict). Dengan cara seperti ini, diharapkan konflik tidak meluas ke seluruh organisasi dan akhirnya mempengaruhi kinerja karyawan. Untuk itulah maka manajer harus memiliki kemampuan untuk mengelola konflik, sehingga konflik tidak menjadi faktor yang mengancam keberlangsungan hidup organisasi, tetapi menjadi faktor yang fungsional untuk meningkatkan kinerja organisasi.

\section{b. Pengaruh Penanganan Konflik terhadap Kepuasan Kerja Di Jurusan Administrasi Bisnis}

Dari hasil uji parsial (uji t) lihat tabel 3. diketahui hanya ada satu variabel yaitu variabel berintegrasi yang tidak berpengarih signifikan terhadap kepuasan kerja. Hal ini dapat saja disebabkan dalam mengenali masalah maupun memecahkan masalah pihak-pihak yang terlibat tidak terlalu memerlukan integrasi sehingga masalah atau konflik yang ada dapat diselesaikan secara individu. Koordinasi kerja yang meliputi bergantung kepada teman sekerja dalam bekerja dan keraguan dalam menjalankan tugas karena tidak terstruktur dalam rincian tugas dapat membuat penurunan kepuasan kerja karyawan. Hal ini berarti konflik yang terjadi akan menyebabkan penurunan kepuasan kerja dan ini didukung oleh pendapat dari De Dreu dalam Alfiah (2013:197) yang menyatakan bahwa konflik yang terjadi dalam organiasi dapat berpengaruh negatif dengan kepuasan kerja. Sedangkan untuk variabel memenuhi memiliki pengaruh yang signifikan terhadap kepuasan kerja dengan nilai signifikansi sebesar 0,007 dengan pengaruh sebesar $26,7 \%$. Untuk variabel mendominasi memiliki pengaruh yang signifikan terhadap kepuasan kerja dengan nilai signifikansi sebesar 0,038 dengan pengaruh sebesar $16,7 \%$. Untuk variabel menghindar memiliki pengaruh yang signifikan terhadap kepuasan kerja dengan nilai signifikansi sebesar 0,016 dengan pengaruh sebesar 22,0\%. Untuk variabel berkompromi memiliki pengaruh yang signifikan terhadap kepuasan kerja dengan nilai signifikansi sebesar 0,001 dengan pengaruh sebesar 40,0\%.

Konflik dialami oleh staf pengajar di Jurusan Admiistrasi Bisnis harus lebih diperhatikan lagi. Mengingat hal ini dapat menyebabkan perubahan tingkat kepuasan kerja. Jika konflik yang terjadi di orgasniasi rendah, maka kepuasan kerja karyawan akan meningkat. Maka dari itu diperlukan pengelolaan konflik yang baikn dengan cara metode manajemen konflik. menjelaskan bahwa ada beberapa strategi untuk mengelola konflik dalam organisasi. Strategi tersebut adalah dengan cara penghindaran, intervensi kekuatan, penggembosan, dan resolusi. Dengan menerapkan strategistrategi tersebut, kepuasan kerja karyawan akan menjadi lebih baik dan perusahaan pun dapat mencapai tujuannya. Mengingat keempat variabel diatas memiliki pengaruh yang signifikan terhadap kepuasan kerja 
maka pendekatan dalam resolusi konflik menurut Gitosudarmo (2000:122) dapat dilihat berdasarkan pada konflik itu sendiri, karakteristik orang-orang yang terlibat di dalamnya, keahlian individu yang terlibat dalam penyelesaian konflik, Isu yang menimbulkan konflik, dan ketersediaan waktu dan tenaga untuk dapat mengelola konflik dengan baik diharapkan mampu menciptakan atau meningkatkan kepuasan kerja. Manajemen harus mampu meredam persaingan yang sifatnya berlebihan (yang melahirkan konflik yang bersifat disfungsional) yang justru merusak spirit sinergisme organisasi tanpa melupakan continous re-empowerment.

Dari hasil uji simultan diketahui bahwa variabel penanganan konflik berpengaruh secara simultan terhadap kepuasan kerja sebesar $17,9 \%$. sedangkan sisanya dipengaruhi oleh faktor lain yang tidak diteliti dalam penelitian ini. Hal ini sesuai dengan penelitian Nugroho dalam Astarika (2007),menyatakan bahwa "Pengaruh Konflik dan Stres terhadap Kepuasan Kerja Karyawan pada PT. Bank Rakyat Indonesia Cabang Kebumen". Dari pegujian hipotesis diperoleh simpulan sebagai berikut: Konflik antar rekan sekerja, konflik antara pimpinan dan bawahan, stres karena beban kerja, stres karena waktu kerja dan stres karena lingkungan kerja mempunyai pengaruh signifikan terhadap kepuasan kerja baik secara bersama-sama maupun secara parsial. Keberadaan konflik dalam suatu organisasi tidak dapat dihindarkan, dengan kata lain bahwa konflik selalu hadir dan tidak dapat dielakkan.

Konflik sering muncul dan terjadi pada setiap organisasi, karena dapat merugikan organisasi. Kepemimpinan dituntut untuk mengefektifkan organisasi melalui kegiatan management sumber daya manusia yang tepat serta harus berusaha mencegah atau menghentikan konflik ini dengan menekan setiap kepentingan yang berbeda, dan diarahkan pada kepentingan bersama atau kepentingan organisasi. Munculnya berbagai konflik merupakan dinamika dan perkembangan organisasi, karena itu pimpinan perlu memahami beberapa sebab yang dapat menimbulkan konflik, dan mencermati konflik sebagai suatu kejadian yang tidak dapat dipisahkan dari persoalan organisasi serta dapat menemukan cara yang paling tepat dalam menanggani konflik.

\section{SIMPULAN, IMPLIKASI DAN KETERBATASAN PENELITIAN}

\section{Simpulan}

Berdasarkan pembahasan maka disimpulan sebagai berikut:

1. Dari hasil uji parsial (uji t) diketahui hanya ada satu variabel yaitu variabel berintegrasi yang tidak berpengaruh signifikan terhadap kepuasan kerja. Sedangkan variabel untuk variabel memenuhi memiliki pengaruh yang signifikan terhadap kepuasan kerja dengan nilai signifikansi sebesar 0,007 dengan pengaruh sebesar $26,7 \%$. Untuk variabel mendominasi memiliki pengaruh yang signifikan terhadap kepuasan kerja dengan nilai signifikansi sebesar 0,038 dengan pengaruh sebesar $16,7 \%$. Untuk variabel menghindar memiliki pengaruh yang signifikan terhadap kepuasan kerja dengan nilai signifikansi sebesar 0,016 dengan pengaruh sebesar $22,0 \%$. Untuk variabel berkompromi memiliki pengaruh yang signifikan 
terhadap kepuasan kerja dengan nilai signifikansi sebesar 0,001 dengan pengaruh sebesar $40,0 \%$.

2. Dari hasil uji simultan diketahui bahwa variabel penanganan konflik berpengaruh secara simultan terhadap kepuasan kerja sebesar 17,9\%. sedangkan sisanya dipengaruhi oleh faktor lain yang tidak diteliti dalam penelitian ini

\section{Implikasi}

Berdasarkan hasil yang telah didapatkan, maka peneliti dapat mengajukan impikasi yang diharapkan berguna bagi Jurusan Administrasi Bisnis pada khususnya. Perlu dipahami bahwa konflik tidak dapat dihindari dalam kehidupan dan dapat merugikan organisasi. Kepemimpinan dituntut untuk mengefektifkan organisasi melalui kegiatan management sumber daya manusia yang tepat serta harus berusaha mencegah atau menghentikan konflik ini dengan menekan setiap kepentingan yang berbeda, dan diarahkan pada kepentingan bersama atau kepentingan organisasi.

\section{Keterbatasan Penelitian}

Diharapkan penelitian ini dapat dilanjutkan dengan menggunakan variabel dan indikator yang berbeda dari penelitian ini berkaitan dengan penangganan konflik dan kepuasan kerja. Sehingga dapat memberikan berbagai alternatif dalam penanganan konflik khususnya. Selain dikarenakan keterbatasan waktu dan biaya diharapkan ada penelitian yang dapat mengakaji tentang manfaat konflik bagi organisasi.

\section{REFERENSI}

Abdurrahman, Maman \& Sambas Ali Muhidin. (2011). "Panduan Praktis Memahami Penelitian (Bidang Sosial-Administrasi-Pendidikan)". Bandung: Pustaka Satria.

Afrizal, Poundra Rizky dkk. (2014). "Pengaruh Konflik Kerja dan Stres Kerja Terhadap Kepuasan Kerja". Jurnal Administrasi Bisnis Vol. 8 No. 1 Februari 2014. Diakses tanggal 6 Juni 2016.

Alfiah, J. (2013). Pengaruh Konflik Terhadap Kepuasan Kerja Melalui Kepercayaan. Jurnal Ilmu Manajemen, 1(1):197-208.

Astarika, Indi. (2007). "Hubungan Antara Konflik Peran dengan Kepuasan Kerja pada PT. Garuda Indonesia", Jakarta.

Ebel, Robert L. And David A. Frisbie. (1979). Essentials of Educational Measurement, Third Edition. New Jersey: Prentice Hall Inc.

Gitosudarmo, I. dan I. N. Sudita. (2000). Perilaku Organisasi. Edisi Pertama. Cetakan Kedua. Yogyakarta: BPFEYogyakarta.

Gujarati， D. (1999). "Ekonometrika Dasar". Alih Bahasa: Sumarsono Zain. Cetakan keenam. Jakarta: Erlangga.

Kreitner, Robert \& Angelo Kinicki. (2005). "Perilaku Organisasi". Buku 2. Edisi 5. Jakarta:Salemba Empat.

Riduan. (2002). "Metode dan Teknik Menyusun Tesis". Bandung: Alfabeta.

Robbins, Stephen P. (2006). "Perilaku Organisasi". Edisi Kesepuluh. Jakarta: PT Indeks Kelompok Gramedia.

Singarimbun \& Sofian Effendi. (1995). "Metode Penelitian Survai". Edisi Revisi. Jakarta: LP3ES. 
Sugiyono. (2005). "Metodologi Penelitian Umar, Husein. (2002). "Metode Riset Administrasi". Bandung: Alfabeta. Bisnis". 2002. Jakarta.

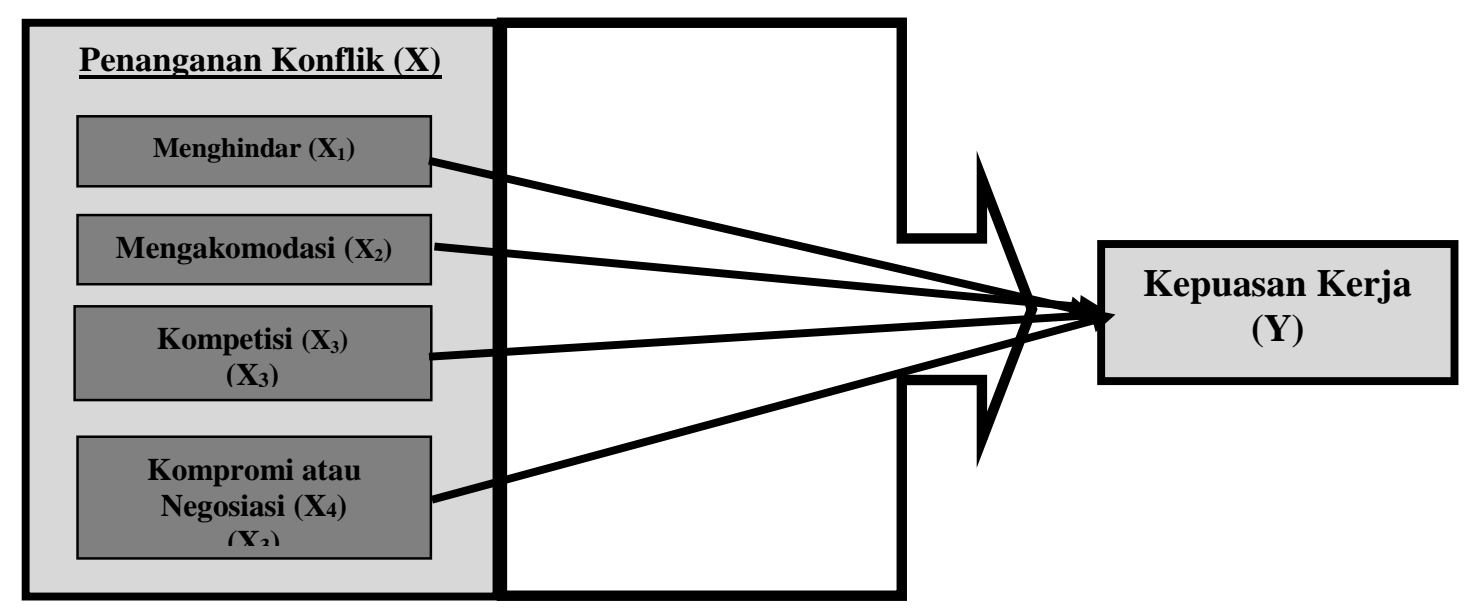

Gambar 1. Kerangka Konsep Penelitian 